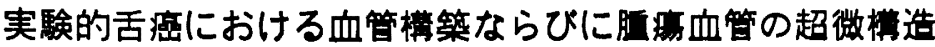

\author{
松嶋典送
}

\section{The ultrastructure of the tumor vessels and the angioarchitecture in experimentally induced carcinoma of the tongue}

\author{
Tsunehiko Matsushima
}

\section{腥}

癌の化学療法において制病剂の腫病局所到達性 ${ }^{1,2)}$ 高めたり，故射線療法において十分な酸素効果》をを期待 する上で，瘦を栄羡する血管の分布，走行，形熊，性状 などを把握することは重要なことである，また樶近再び 注目を集めている温熱療法い゙）においても，腫疸内循環 の果たす役割は大きいものと思われる。

腫㿇血管は以前より注目され，胃癌・大晹癌など7 11)

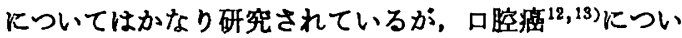
ての報告は極めて少ないようである，著者は口空癌の血 管構築の解明を試みたか，臨床例において十分にそれを 観察することは手法上極めて图難である。.そこで，八ム スターの 9, 10-dimethyl-1, 2-benzanthracene（以下 DMBA)による実検的発生舌密14,15) について血管構築の 観察を行った。

特に，正常粘膜の固有㒶の血管から腫瘍血管への移行 や，腫湯細胞との関係などを検討して，腫晹血管の特徵 を把握するために，正常粘膜から発癌に至るまでの血管 構築の変化を段階的に追跡した．また，透過電影により

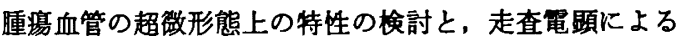
腫瘍血管内腔の立体的観察も行った.

\section{材料および方法}

\section{1. 材 料}

実験動物は，生後 5 週の雄ゴールデン・ハムスター60

九州大学菌学部口腔外科学教室第 1 講座（主任：田 代英雄教授）

First Department of Oral Surgery, Faculty of Dentistry, Kyushu University (Chief: Prof. Hideo Tashiro)

九州大学畨学部口腔解剖学教室第 1 绕座（主任：長 谷川一夫教授)

First Department of Oral Anatomy, Faculty of Dentistry, Kyushu University (Chief: Prof. Kazuo Hasegawa)

受付日：㹦和56年 9 月 18 日
頭を用いた，光顕用に45顕，走亘電顕用に 3 頭および透 過奄顕用に12頭用いた。

\section{2. 発庶操作}

発癌剤は $0.5 \%$ DMBA アセトン溶液とし，週 6 回エー

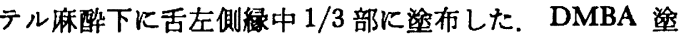
布後経時的 ( 1 週ないし 2 週間隔)にハムスターを屠殺し 標本を作制した，実駼期間は途布開始より30週である。

3. 光顥標本作製法

光影的に血管構筑を把握するために，燢计注入標本 ${ }^{16)}$ を作製した，作製法は，まずハムスターをエーテル麻醉 下に開胸し，左心室より $5 \%$ ゼチン添加壘计を注入 後，ゼラチンが完全に硬化したのを確認した啳，舌根よ り舌を注意潹く切離し10\%中性フォルマリンで固定し た。 その後水洗・エタノール脱水系列を経た後舌をセ口 イシンに包埋した。 ブロックは舌尖より舌根にかけて前 類断に200 $\mu$ の厚切りの連続切片とし、これを Spalteholz 氏透明標本 ${ }^{12)}$ とした。 また随所に $10 \mu$ の薄切切片を入 れへマトキシリン・エオシンン染色用の標本とした， $200 \mu$ の厚切り透明標本で血管藉築を，また10 $\mu$ の海切染色漂 本で同部の組織学的検索を行った。

4. レジン鉡型標本作彆法 ${ }^{17 ~ 19)}$

ハムスターをェーテル麻醉下に開胸し，左心室より大 動脈弓までテフロン・チューブを挿入し，これを結禁固 定し，生食水で血液を整流させたのち常温重 合レジン （Mercox）を強王をかけずに注入した．碑がレジンの色 を帯びさらにレジンが心臟に還流してきた時点を，注入 終了の目安とした，レシンの硬化後, 注意深く舌根部よ り舌を切離し， $20 \% \mathrm{KOH}$ K1 か月浸清し周囲軟組織 を腐強除去した，次に生食水で数回洗浄後鋳型標本を涷 結乾燥させ，毛細血管鋳型標本を完成させた。この標本 を実体䫒微鏡下に切り出し，金蒸着を施した後走査電子 䫒微鏡 (Hitachi S-430) で観察した。撮影条件は，加速 電圧 $20 \mathrm{Kv}$ ，倍率30３00倍フフィルムはネオパン SSを 使用した。

\section{5. 透過電影標本作製法}

左側舌縁病巣部を注意深く細切し，Karnovsky 固定液 で前固定 1.5 時間， $1 \%$ オスミック酸で後固定 1 時間を 
施しエタノール系列で脱水した後エポン812 に包埋し

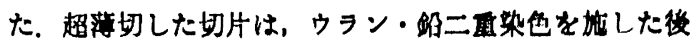

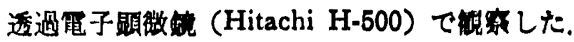

\section{結}

\section{果}

\section{DMBA 布後の肉眼所見}

DMBA を反得布すると，早いものでは3週目より

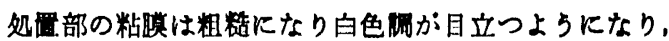

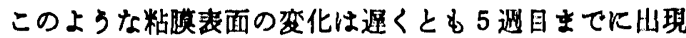

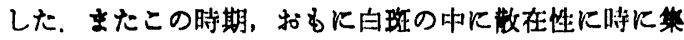
合性儿，数個の白色ないし灰费白出の小点状隆起が汉ら れるものが多かった，その後早いものでは10迥唄より，

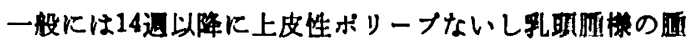

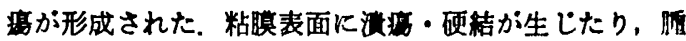
瘍の急速な成長中，全身的に高度なるいそらか照められ， 明らかに癌を思わせるのは処粗後20週からであり30過ま でとすぺて癌が発生した。

\section{2. 肉眼所見と組䄳所見との関逗}

DMBA 染布後 2 週目までは，舌粘膜は肉眼的・組織 学的に正常粘䠑であった．3 週目を境に一部の症例に白 板症侎の粘莫表面病变が出現し，これらのらち処置後 3 週より12週までの早期群においては組織学的に良性過角 化症であった，この場合若干の上皮脚の延長はあって も，過角化がその主たる所見であるものは，すべてこの 分類に含めた。11週以後16週目までの群ではほとんどの

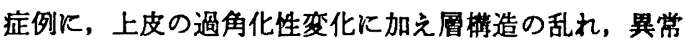
角化などの異角化性变化がみられ，異型上皮の所見を示 した. また14週目と16週目の症例の一部に構造異型・細 胞異型ともに高度であり下方への浸润傾向を示さないる のがあり，これらは高度異型上皮ないし上皮内癌とみな されるすのであった。 このような所見を呈するものは30 週目の症例でるみられ，この場合は外向性発育を示す病 に近接するロ底よりの舌粘膜に俧められた。

外向発育型の腫瘍では，10週目の症例の舌側崡肉に上 皮性ボリープ発生をみた注かは，すべて乳頭畽あるい は扁平上皮癌であった，乳頭腫と診断した14䓢目の症例 は，口底より舌側電肉にわたる領城よりポリーブ状に発 育するものであった，典型的な乳頭腫様発育を示するの は，18週目の左側舌縁より口底・舌側歯肉にわたる領城 に発生したるのであった。

癌と診断したすのは一般に20週以後に出現したが，16 週目にみられた 1 症例は早期浸润癌と思われるものであ った. はとんどのるのは外向性発育を呈したが，27週目 の 1 症例のみは渍湯硬結型であった。

3. 上皮の組織学的変化と血管変化との関連

a. 正常上皮に护血管構筑 (写真 1,2)

舌縁上部より舌背にわたる領域は釆状乳頭が存在し角 化の比較的高度な部位である. 上皮脚の発達は良く, 間
買釈瑱内にはそれぞれ1本ナ゙つ正常へフピン得ないし1

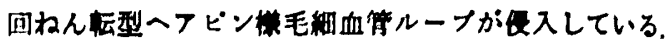

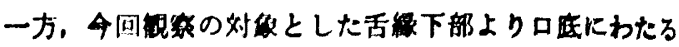

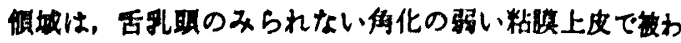

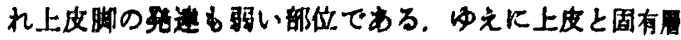

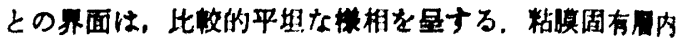

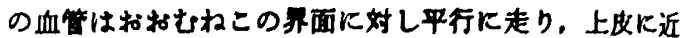
接している血管群と舌施上方を平行に走る血管群とから 模成されている。これら平行に走る血管は所ィで互いた 物合枝により速絡している，上皮に近接して表る血管の 场合，なだらかに上皮に奶し平行に走るが，所ネ下不完 全型のルーフ形成がるられる，つまり，粘䀧聚面に奶し 平行な面上で，二次元的な広かりをいつ血管形形成し

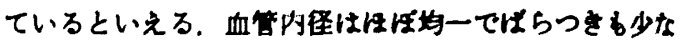

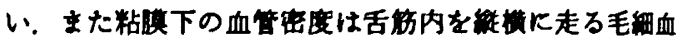
管と比较するとはるか低い状筧にある。

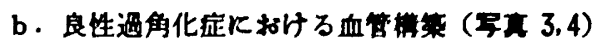

既存毛細血管縞上り上皮方向へ血管ループ立ち上が りがみられ始める。しかし，この時期はまだ有揀細图用

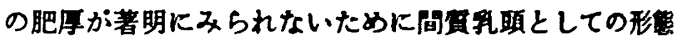
か明らかではない。よってルーブを形成したとしてい不 完全型である．過形成のみられる上皮下の毛血管は全

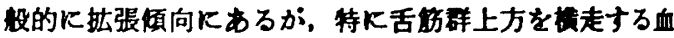
管の払張の方が著明である，血管客度は上㫒㑯向飞あ ろ.

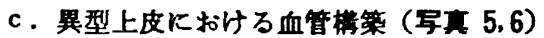

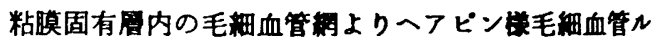
一ブが粘漠表面へ向けて伸長し，過形成のみられる上皮

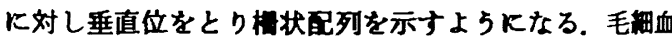
管ルーブは間䨘秏頭の上部までくまなく唚入するため に，上皮脚の発達が良く下方へ十分に伸びているるのは どそれに対応して毛細血管ルーブもその基成部より先端 までの長さが伸びる．上皮脚がさ注ど下方へ伸びていた い場合でる，ルーブ状毛㽞血管の立ち上がりの兆しが られ始める。このよ5に翼型上皮直下の血管走行は，米 状乳頭部の血管構築に頼似してくるといえる，毛梱血管 内径は，健㑡ならびに病巣周囲の既存毛細血管之比㪟す ると明らかに払張している．全体的に内经の払張がみら れるが，そのばらつきる大きく内径が不规則であるため に全般的にふしくれだってみえる，特に扗張の強い箇所 では静脈湯様にみえることがある。このよらな払張部 は、ルーブ先端付近にみられることが多いよらである。

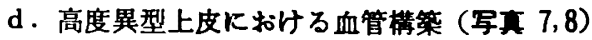

上皮直下を横走する血管網より種々の形態をなす毛細

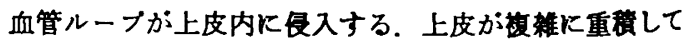
いるために，上皮内の毛細血管ルーブす粘膜表面に対し 垂直位を示す成分のみならず氷平位をとる成分す多くな り，Y字型ルーブやねん転の頻繁なルーブを形作ったり 総して高度な変化を示すようになる，単純なへフピン様 
ルーブははとんどみられない，毛細血管は上皮内に茜苗 に唚入し，上皮のかなり上方まで逢するし，綖㯕に走る ために上皮内の血管密度は高いるのになっている，上皮 内では 1 本の血管とごくわずかな結合峨を芯にして間筫 を形成し，その周囲を同心円状に viable な上皮細胞か： 配列するために，正常な上皮の屈橉造は完全に失われ， しかも上皮細胞ははとんど viable な状態を示す。また 上皮内各所飞は，単一細胞角化や角基真珠の形成などが みられ異角化が著明に䞏められる。

e . 上皮性ボリーブ・乳頭睡における血管楼築

上皮性ボリーブ・乳頭腫いずれです，血管橉築の面か らは同棣の所見を呈するすのと思われる，1本の比校的 内径の大きな主龫血管が尰癌外表方向に走り，その経過 中各所飞おいて故射状に外方へ分枝を送る。それらはそ のま，あるいはさらに分岐をくり返し暦䅂的にはその 末梢枝は腫疸間貿乳頭内に深く仅入する。このよらな榯 枝状血管粠策が上皮性ボリーブ・乳頭腫の際の基本単位 であると考えられる（写真 9 ).

これら分枝血管の末端は静脈瘁様あるいは数珠状に払 張していることが多く，花火が散ったような感を与える のが特徵である，一部その数珠状払張部より，鹿の角状 あるいは指状の突起が盾激表層方向へ伸びている像すみ られる. 乳頭腫の場合全般的に比較的大きな血管から構 管されており，細い血管による蜂巣状血管網の形成はみ られない。また血管内径は比較的大きいが，その構築が それはどち密でないために血管密度は中等度となってい る. 腫湟径が大きくなるにしたがい血管密度は低下して くる.

f . 癌飞おける血管構築

1) 外向発育部 (写真10)

この部分は，いわゆる癌固有間質を形成しているとこ ろである. 癌固有間質内には通常次の 3 種の血管群が琵 められる.

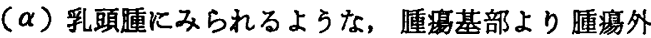
表方向に放射状に固有間質を貫いて腫場上皮下に達する 血管群 (写真11).

( $\beta$ ）癌固有間質内で，塊状・球状あるいは島状をな す比較的大きな癌胞巣の表面をとりまく血管群（写奥 12).

（ $\gamma$ ）癌固有間質内を，細網状に分岐走行し，蜂巣状 血管網を形成する血管群 (写真13).

癌固有間質の発達の程度により,これら3 種の血管群 はその構成量比に变化をきたしてくる，間質の発達が良 好な腫湯では各血管群の発達も良いようである。ことに （）群の発達が著明となり，腫場内血管密度は高くな っている（写真14-a)，一方，間質内に多量の癌胞巣が 形成され，相対的に間質が乏しくなってくると $(\beta)$ 群 が優勢となり， $(\gamma)$ 群が減少してくるために腫場内血 管密度は低下してくる，ことに癌固有間質を癌胞巣がほ

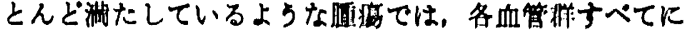
減少がみられ血管密度が非常に低い揰瘍となる（肎西 14-b).

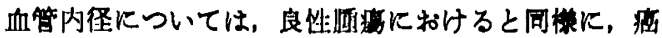
においても明らかに内径の大をな血管が慜められる。 た走行中に内径が不規則に变化するために，心しくれた った奇促な像を旺する。（ $(\alpha)$ 稀の血管内径は，他の 2 群のそれに比べはるが大きなものである。 またこの血 管群は末端部で異常な抁張がみられることが多く，敞脈

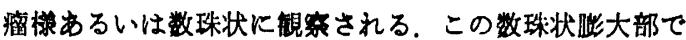

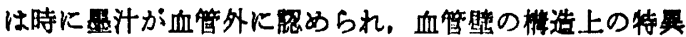
性が示唆される。

\section{2）内方漫洞部}

この部分は嗹疡細胞の浸潤により，既存正常組織が破 壤をらけ，偶然間質が形成されるととすに，正常組織飞 おけるとは全く異なる毛細血管網が再構筑されている。 この部分はほとんど大小多数の癌胞巣により占められて いることが多く，間質の発達は不良である，そのためこ の部で認められる血管型は癌胞巣表面をとりまく血管群 （ $\beta$ 群）が主体であり，残りは $\beta$ 群間の間質を網状に走 る血管群（ $\gamma$ 群）が少量みられるのみである．また外向 発育部に認められた $\alpha$ 群は全く琶められず，そのため外 向発育部の血管粠築は樹枝状粠等が主体であったのに反 し，内方浸潤部では $\beta$ 群が主体をなすため，いわばシャ ボン玉状血管構筑として翟められる（写真 15）。また血 管がシャボン玉状粠筑をとっているために，血管密度は 低くなっている。

正常組樴との境界部では，癌細胞の漫潤方向に一致し て走行する既存毛細血管は比較的保存されている，そし てこの保存された既存毛細血管群の間に，肥大発育型の 癌胞巣より続発性に生じたと思われる瘦細胞の小集団が しばしば認められる。つまり，このよらな正常組織との 境界部では，癌実質はいわゆる簇出発育型を示すといえ る. そのためこのような部位では，正常組織より肥大発 育型癌胞巣の方に向から棚状血管網として翟められる （写真16），一方，球状の癌胞巣をなし，肥大発育性飞周 囲健常組織と明瞭に境している部位では， $\beta$ 群に相当す ると思われる血管が著明に払張しているのが琵められ る.

\section{4. 腫埸血管の超微形態的所見}

\section{a. 一般的所見}

1) 内皮細胞

最る特徵的な所見は, luminal process の存在である. これには一部 marginal fold の延長したものも認められ るが，ほとんどのものは内皮細胞管腔側全域より管腔へ 向けて，指状・波状・渦状などの突起を突き出している のが認められる(写真17)，腫場血管によっては，luminal process を多数有するものもあれば，極めて luminal process に乏しいものまで種々の変異がみられる. 


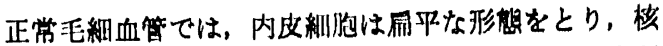
のあるところにしてす柽度管腔㑢へ隆起しているにすを゙

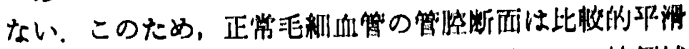
な類円形を呈している，ところが阿血管では，核悓城 が立方円柱状に管腔側へ立ち上がっているむのが多く， 核のない部分です正常毛紐血管に比へ示くなる㑯向にあ

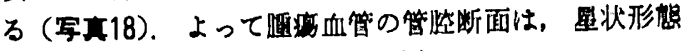
なと不規則な内面を形作ることが多い。

管腔は多数の内皮細胞の連絖よりなるるのが多く，あ るものでは10個以上の内皮紐胞からなるものむ思められ る、各胞体は明調を示するのから胉晭を示するのまで，

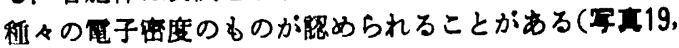
24).

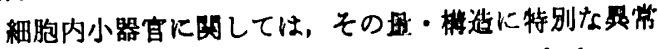

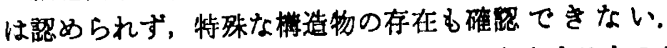
mitochondria は粗面小胞体に近接して存在するものが 多い，粗面小胞体は比校的発達しているよらである。 pinocytotic vesicle はすべての腫瘦血管に梕められる が，特に肥大を示す内皮細胞にはより著明に钼察され 乃.

\section{2) pericyte}

内皮細胞基底膜外側飞，扁平な細胞として存在する。 pinocytotic vesicle は間質側に局在していることが多 い。また，胞体内には細胞内線䊒が豊富に琵められる (写真18～20).

\section{b . 腫湯血管の形熊分類}

毛細血管の形態分類については，従来より内皮細胞の 形態的特徽から分類を行っているものが多い20022). 今回 の尰湯血管の形態分類に当たっては, Bennett $5^{20)}$ の分 類に準じた。

1) fenestrated type (写重 21，22）

この種の血管は癌胞巣に近接する隀疸血管に特徽的に 観察される. 癌胞巣側の血管内皮細胞柱全体的に扁平で 菲薄であり，癌胞巣側に限って所々に fenestration がみ られる。また，癌胞巣側では一般に単一の内皮細胞から なっていることが多いために, junction 形成はあまり 観察されない.しかしまれにみられる junctionは 胞体が扁平であるために直線的な経過をとり，しかむ junction 部の間隔は広く open channel のような状態 を呈する，基底膜は所々で多層化がみられたり，あるい は不明瞭な場合すあるが，概して連続性であるといえ る. pericyte はあるすのとないるのがあり, pericyte の 観察される場合です，その存在領域はわずかなるのであ る.

2) continuous type

この種の血管は癌胞巣から離れた腫瘍間質中に認めら れる.内径の大きさと内皮細胞の肥大の有無により，は ほ 3 種の血管に分類される.

a ）内径か比較的大きく，内皮細胞に肥大がみられる

\section{るの (军直23)}

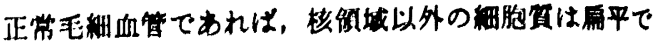
非满な形態を示ナのであるか，この得の血管では，肥大 した内及緗胞からなり非常に舆常な形僁をとっている。

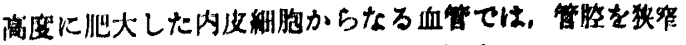
してしまらはどのるのるある. luminal proces の発道 は中等度で，代状・短槙状の突起が主体である。内皮細

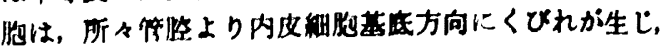

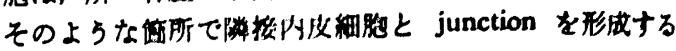
ことが比制的多い。

b ）内径が比赖的大をく，內及緗胞に肥大がみられな いもの (肎两24)

この程の血管は，西子密度がそれぞれ罢なる多数の内 皮緗胞の速繶からなる。

c）内径が比教的小さなるの（军【25）

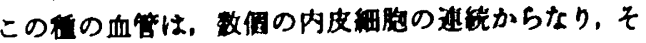
れら内皮細胞の元于密度に变化はみられない。

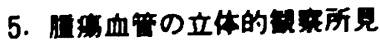

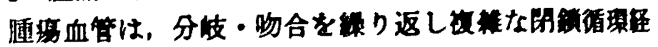
路を形成していた。畽血管末端部では，接血管との 吻合あるいはルーブ形成はあまり就められず,多くは策

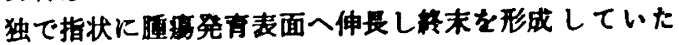
(写五26).末端部の一部の筒所では,ルーブ先端より鹿

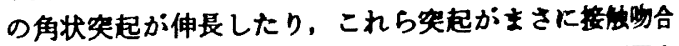
しルーブを形成しよらとしている像る路められた（写真 27）。たある部位では，末端が小球状の莱団境をなし カリフラワー㥆にみえるところるあった（写面28）.

高倍の制察では，血管内隆面形態は平滑な性状を示さ

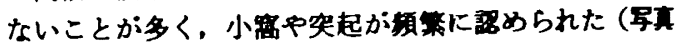
27).

\section{考㝓}

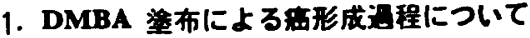

本実検では，小田島らの報告汭とよる通 6 回 DMBA

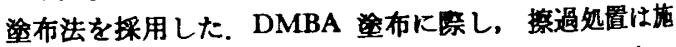
さなかった，理由は，感染等の因子を除外するためと，

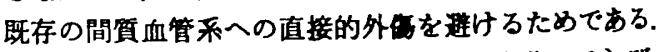

藤田ら ${ }^{23}$ 沬，舌患の形成週程を，1）初期，2）びま 几性增生期，3）乳頭畽形成期，4）癌形成期下分頼し

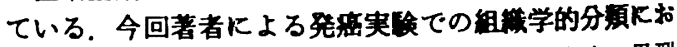
いて，正常上皮は费田らの初期に，良性過角化应・異型 上皮・高度異型上皮はびまん性增生期に，上皮性ボリー フ・乳頭腫は乳頭隀形成期飞，また海は䖽形成期飞相当 するるのと考えられる. 各段階の出現時期には, 多少す れを琶めるものの，発癌過程の流れにおいて共通性がみ られる. 本実検においてる，先人の所見と同しょらに， 上皮性ボリーブあるいは乳頭腫といら段階を踏んで澏化 するむのがほとんどであり，外向発育ははとんど示さず 
に内方浸澗だけを示す型は非常にまれであった，一方，

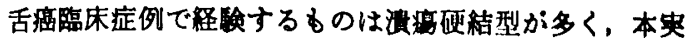
検で钼察されるよらな外向発育形態を示するのは比洨的 少ないよらである.

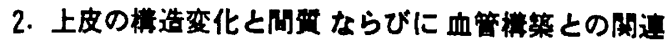
について

\section{a. 正常上皮より良性過角化症への移行}

良性過角化症では単に角化層の增生がみられるのみで あり，一部軽度の上皮脚の延長が琶められるにすぎな い. 一応この段階までは，発漓剂の刺潄に対する反応生 の上皮細胞の增殖機転の六進として考えられる. Sekiba

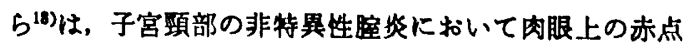
に対応ナるるのとして，ヘフビン㥞權造の protruding vessel を報告している，良性過角化症における，间䨘秏 頭内へ侵入するへアピン權毛紐血管ルーブは，この protruding vessel に相当するるのと洘えられる.

b. 良性過角化症より異型上皮ないし高度異型上皮へ の移行

この移行時期においては，上皮細胞の增殖はますます 旺盛になり，上皮脚の間質方向への伸畏が優熬になって くる.そこで間貿の方向より，上皮と間筫との界面の形 態を涀察すると，基底細胞層は増殖のために必要な酸素 ・栄養を十分かつ始率よく䭪得するために，その表面程 を增しているのが観察される．そのため，この祭の上皮 の構造変化を，単に上皮細胞の過度の增殖による間貝方 向へのはみ出しとして把握するのみではなく，酸素・柴 養獲得のための上皮細胞の active migration ${ }^{24,25)}$ による すのとも考える必要があると思われる.

この段階での血管構筑は既存血管網よりの毛細血管ル 一ブの立ち上がりとして表現しらるか，この現象は上皮 の下方への増殖の結果による相奶的な所産ではないと考 えられる、なぜなら，既存血管網が下方へ王排されてい る所見は全く認められず，比较的正常な構筑を保つ血管 網より毛紏血管ルーブが伸長しているからである。この ように考えるならば，毛細血管ルーブが伸長するために は，基底紐胞㬝と既存血管網との間の間筫結合織の增大 あるいは，上皮構造変化に対応した間質形態の随伴性変 化が必要となろう。

\section{c.上皮性ポリーブ・乳頭尰への移行}

この種の外向発育型腫湯では, 既存血管網より腫湯外 表方向へ主幹血管が伸び, それらの末梢枝は各間質乳頭 内に入り込んでいる. 間質増生量と上皮増生量との量的 関係により，上皮性ボリーブより乳頭腫までの病㑷像の 移行が観察される.この場合, 間質增生と血管誘導が, その尰晹の外向発育形態に寄与していることは疑いのな いところである. 乳頭尰にしてもその発育中心か上皮に 優位ではあるるのの，若干の結合組織ならびに毛細血管 を芯にして間質乳頭を形成している点から，外向発育に

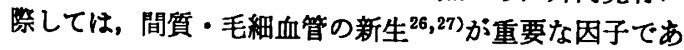

\section{ると散えられる。}

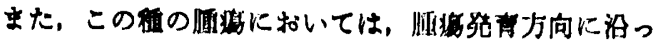

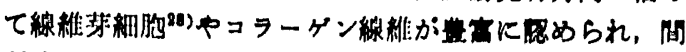
賞确生が活発であることがらかがわれる。したがって，

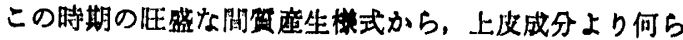

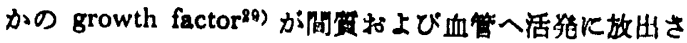
れていると帣えられる. Folkman ${ }^{80,81)}$ かi in vitro およ び in vivo での实触で示唆している TAF とい5 growth

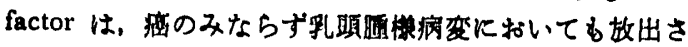
れているのであろら.

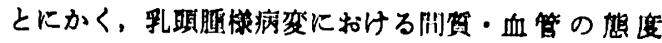

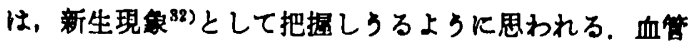
新生現象は，胎生期における未分化间葉細胞の接合によ

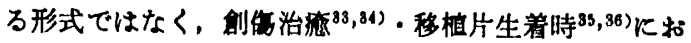
けるよらな出来現象によるすのと考えられる。

\section{d. 瘦への移行}

小林 ${ }^{13)}$ は, DMBA 铮発ハムスタ一舌癌において血管

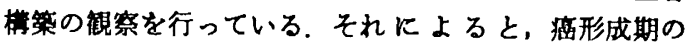
Microangiogram は, いわゆる tumor-stain 像を呈し，

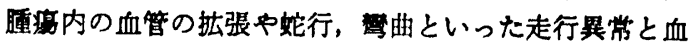
管分布密度の增加が著明であるとしている.今回の実険 結果からも，ほぼ同棣の所見を得ることができた，著者 は，腫暍血管をその走行と分布形式により 3 群に分頼

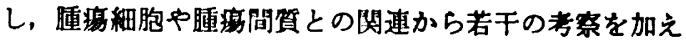
る。

\section{1) 外向発育部}

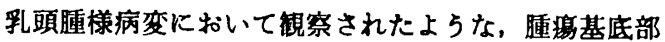
より放射状に走る血管（ $\alpha$ 群）は，痤の外向発育時の中 心的役割を担っているといってもさしつかえないくらい 重要な要素であろらと考えられる，癌胞紧周囲をとりま く血管 ( $\beta$ 群) は，その胞県を形成する癌細胞の酸素・ 栄瓦供給を担っていると思われる.この場合, 間貿中を 移動しているであろらと思われる単一あるいは数個の病 細胞よりなる小吵団には血管の誘革がみられない。これ ら小集団の細胞配列には, 球状形態をなす肥大発青型胞 果にみられるよらな規則的な層棈造は認められず, しか むすべての細胞は viable な状態を示している，次第に 胞策を構成する細胞数が增加するにしたがい, 球状胞巣 を形成してくるとともに，血管 ( $\beta$ 群) による胞果の囲 暁が琶められる。この種の胞巣では，血管に近接する細 胞層のみ viable な様相を呈し, 胞巣の内方領域は次第 に nonviable となり, かなり胞㸺の径を増すにつれて 中心部は壞死の状態に陥ってくる.このような球状胞巣 の形成は，効果的なガス交換や，栄㙋吸収・老廃物の排 泄が円滑に進行する上で，好都合な形態をなしているよ らに思われる。

酸素供給の面から考えると, 理論上酸素到達域は血管 より $180 \mu$ の範囲とされている37). この点からも, 比較 的大きな胞笨を形成する細胞群が viable な様相を呈し 
cell cycle88)を回るには，胞果への血管膘第が必要なの

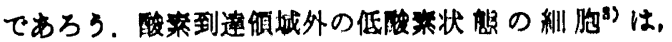

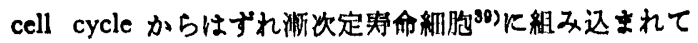
いき坡死領城へ策穔するものと思われる。

2) 内方浸潤部

本实埃で症例に括いては，びまん性に浸洞する型は まれであり，注とんどのるのは肥大発育型の痁胞紧を形

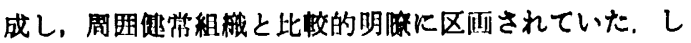

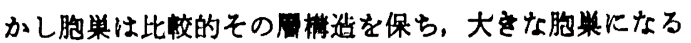
とその中心部は角化性变化あるいは䯚死性变化をきたし ていた，つまり，商分化型癌の所見を示するのであっ た，この形式は，一旦釈頭睡棁病变が形成され，その後 上皮の一部に癌性变化をきたし内方浸泪を明始すると考 えられるこの很の発癌实険モデルの特徽といえるかむし れない。

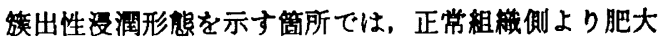
発育型胞巣へ向けて柵状血管が翟められたか，この得の 血管は新生血管とは考之にくいよ5に思われる，といら のは，一見していわゆる腫瘍血管のよ5に内径が大小不 同で走行が不規則であるといらことがなく，正常血管の よ5に均一な内径の血管が規則正しい配列をしているか らである、また実祭，周囲の残存している舌筋毛細血管 と対比してみると，栅状血管内径は舌能毛細血管のそれ と同じであり，走行に関しても漫潤方向に一政しない既 存毛細血管成分のみが消去された配列棣式をとってい る.このことは，癌細胞漫潤に際して一種の障壁的働き をすると思われる血管成分にのみ侵巽 ${ }^{40} か ゙$ 起こり，比較 的浸潤方向に一致をみる血管成分は温存されるために梅 状血管配列を示すすのと考えられる。しかる，この保存 された柵状血管を利用した形で，当初癌細胞の移動が起 こるすのと想像される.

\section{3. 腫晧血管の超微形慜について}

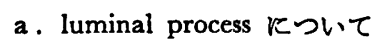

内皮細胞自由表面認められる扁平なヒダ状の突起に ついて, Long") は luminal process と表現し, Ang ${ }^{10)}$ は pinocytotic process と命名しているか，とすに腫湟 血管における物質の大量輸送形態に関与しているすので あろらと述べている。

今回の所見からあ, 突起先端部が波状・滆状に屈曲し 血漿成分を包み込むような様相を呈したり，先端部が管 腔表面と窟合し大きな vacuole を形成しているのが钼 察された ${ }^{41}$ 。 また，この付近の内皮細胞胞体内には，こ れらの突起の取り込みによるるのと思われる vacuole を 認めた. さらに vacuole 中の fuzzy material は奄子密 度の上から血奘成分であるように思われることより、こ れら一連の過程はやはり, luminal process の飲細胞運 動による血漿成分の管外輸送形態を示しているすのと理 解される。

腫瘍血管は内径が大きいことに加え，luminal process

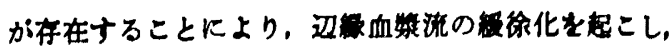
物寞交换の能率を高めているであろらと想像される。

b. junction 形態について

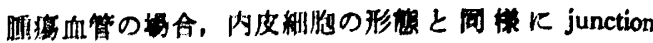
形態す多椂性を括びている。

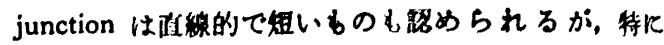
continuous type の血管で内皮細胞に肥大のみられる。 のでは, junction 形喼が状をなしたり届曲・它行が

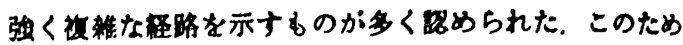

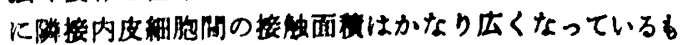
のと思われる。 また，junction 付近の内皮細胞绝体中

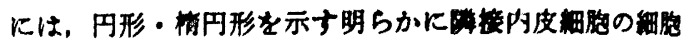

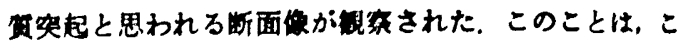

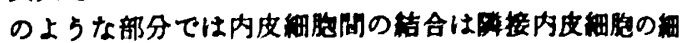

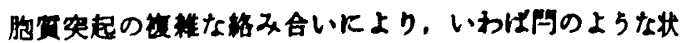
愁を星しているるのと思われる。

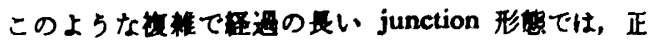

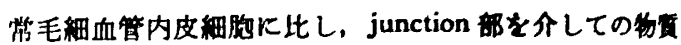
榆送能率は低下しているいのと思われる。 今のところ，

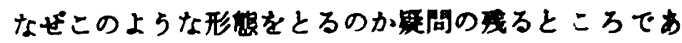
ろ.

一方, fenestrated type の血管では, 胞策们の junction は比較的直線的で単视な形隹をとっており, しかる

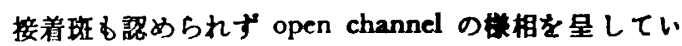

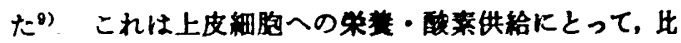
較的自由な物質榆送通路を提供しているるのと解され 万.

\section{c . 内皮練胸间の西子密度の差について}

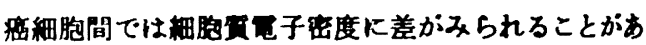

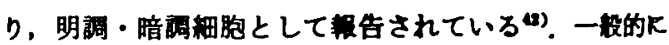
は，細胞䨘中下多昷の ribosome が存在することによ り，奄子密度が高くなると考えられている。 また， ribosome の密度が高いことのはかに, mitochondria の matrix の㫣子密度が高いことも，梱胸を暗調にする要

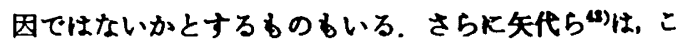
れら明・暗 2 種頛の細胞はとるに变性細胞であろらとの 解粎を加えている、いずれにしてる，相胞内小器官特に ribosome の甚あるいは梱胞内小器官の特性が関与して いるものとみられている。

今回, 腫掦血管内皮細胞で靚察した明調・暗調細胞を 比較してみると， ribosome. mitochondria などの相胞 内小器官の量には大差なく，また変性所見る認めること ができなかった，明調細胞においては暗調細胞に比し， 細胞質基質中の線雃性成分(microfilament, microtubule) あるいは滑面小胞体が少ないようにみうけられた。しか す, 暗調細胞よりる多くの pinocytotic vesicleが内皮細 胞全域にわたり，比較的密に存在していた。これらのこ とより，細胞内小器官の量・性筫がその龟子密度下影䇺 しているのではなく，むしろ細胞質基質中の線䑾性成分 


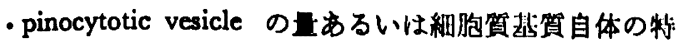
性のちがいが反映しているすのと思われる。つまり， pinocytotic vesicle の增加により，むるいはその垃加が

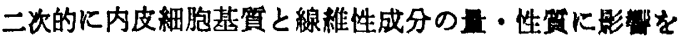

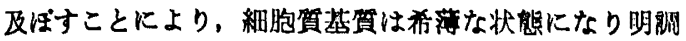
を呈してくるのであろら。このような解釈に立つと，明 暗 2 䅜の細胞は癌細胞におけるよらな变性所見ではな く，しろとすに活発に物貫交喚を営む細胞であろらと 考えられる。

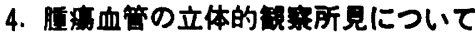

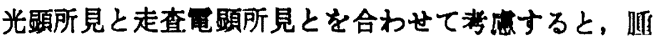
疸血管先端部すなわち血管新生が活発であろらと思われ る部位では，新生血管は通常盲管をなして成畏するもの と思われる。

ところが，カリフラワー㙌要の小球状集団塊は，その 形態があまりにも明瞭な球形を旺していることから、レ シンの管外漏出所見としての可能性が強く，また光顕標 本においてす一部末端で涅汁が血管外に琴められたこと から、このよらな筒所では血管壁が脆弱であるか，ある いは血管末端が時に開放性になるのかもしれないと考え られる.

レジン鋳型に刻印された陥凹は形態ならびに大ささよ ク内皮細胞の核領域あるいは管腔側へ突出した内皮細胞 胞体の状状隆起を表し，一方小窝は luminal processに 対応するるのと解釈される。

\section{5. 腫㨽血管の新生について}

腫場血管の新生現象は，透明空 ${ }^{32)}$ やウサギの角膜 ${ }^{27,30,}$ 31)を利用して動態的に観察されている.なかでる山浦32) は, ラット透明空に移植性腫贼 AH 109A を移植するこ とにより，腫場血管の動態を経時的に覞察し詳細な報告 を行っている。それによると血管新生過程はまず毛細血 管の静脈瘤様拡張が起こり,そこで新生血管芽が形成さ れ，指状の盲管となり隣接する他の血管芽と接触吻合し てルーブを形成するという，ルーブは払張し再び静脈瘤 様になりこれからまた新生血管が成辰し，これらの過 程がくり返されることにより新生血管網が形成されると 述ぺている.

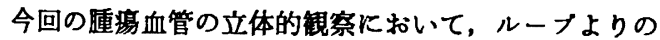
鹿の角状突起の伸長や，これら突起がまさに接触しよう としている像が観察されたことより，腫湯血管の新生は 山浦の報告したと同様な出芽によるものと推測される。 しかし今回，超钽形態上内皮細胞にほとんど分裂像がみ られなかったことやここく短時間で腫瑒のすみずみまで 行きわたる血管網が構築される点などから，いわゆる間 葉反応による間葉細胞の集合 $\left.{ }^{2}\right)$ 。腫湯血管新生過程に関 与しているかるしれない.

\section{結 的}

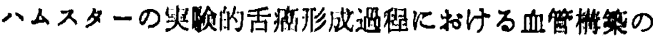

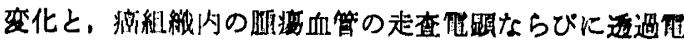

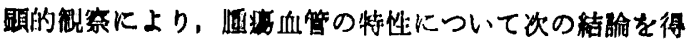
た。

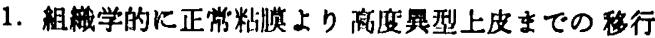
段階における血管權策の变化は，既存毛細血管網上りの 毛紐血管ループの立ら上がり，内径の払張として微察さ れた。

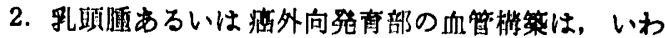
ゆる樹枝状血管椾勧を莀本としていた。

3. 瘦内方源洞部では，瘦胞策周囲を取り囲さ血管群 が主体であり，いわゆるシャボン玉状血管棈策をとって いた。

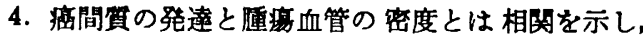
間筫の豊富なもの任ど血管密度は高く，間筫の乏しいも の性ど低い傾向を示した。

5. 光顕および走查奄影的锰察より，隀疼血管は盲端 をなし，既存毛練血管網より出芽により形成されるもの と考えられた。

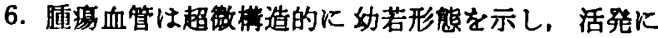
物筫交換を営む新生血管であると思われた。

稿を終わるに䠛み，終始こ想篤なるこ指学とこ校閲を 踢りました田代英雄教授に深甚なる感謝の意を表しま

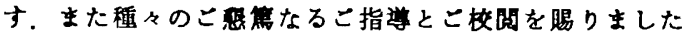
本学第 1 口腔解剖学数室, 長谷川一夫数授に心から謝意 を表します。ささらに本研究を行5にあたり,こ数示,こ 協力を頂いた本学口腔外科学教室員各位, ならびに本学 第 1 口腔解剖学教室員各位に感謝致します。

本論文の要旨（の一部）は第35回日本口腔科学会総会 （東京，1981）において発表した。

\section{引用文献}

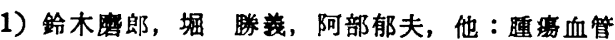
の機能的特殊性。癌と化学缭法 6:287 1979.

2) 東 健彦, 土屋雅春，三島好雄編：䵊少循摆. 第 1 版, 中山㽞店, 東京, 1979, 125頁.

3) Kallman, R.F.: The phenomenon of reoxygenation and its implications for fractionated radiotherapy. Radiology 105: 1351972.

4) Hornback, N.B., Shupe, R., Shidnia, H., et al.: Radiation and microwave therapy in the treatment of advanced cancer. Radiology 130: 4591979.

5) Fajardo, L.F., Egbert, B., Marmor, J., et al.: Effects of hyperthermia in a malignant tumor. 
Cancer 45: 6131980.

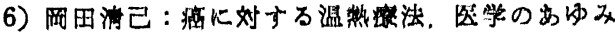
107: 3911978.

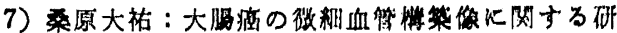

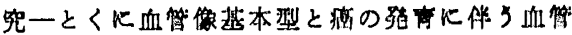
像の変退について一。医学研究 50: 11980.

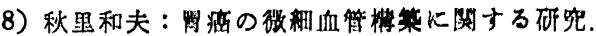
度底医学 50：21 1972.

9) Long, D.M.: Capillary ultrastructure and the blood-brain barrier in human malignant brain tumors. J Neurosurg 32: 1271970.

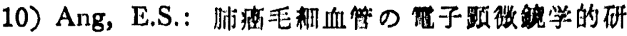

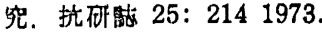

11）樶村秃洋，松山金良，柔原大㤑，他：Borrmann

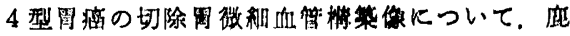
大医誌 29: 5271978.

12) Schmidseder, R.u. Noma, H.: Die Gefäßarchitektonik des Plattenepithelkarzinoms der Mundhöhle. Dtsch Mund-Kiefer-Gesichts-Chir 1: 41977.

13）小林光道：DMBA 誘発ハムスタ一舌病に対す る放射線奻果の研究。畨学 68: 7001980 .

14）藤田浄秀,贺来 事, 佐々木元督, 他：舌瘦の夷 験的形成に関す万研究, 第 1 編, 9,10-dimethyl1,2-benzanthracene の染布による舌瘦の実臨 的形成。口科誌 21：999 1972.

15）小田島哲世, 藤田浄秀, 賀来 宁, 他：舌澏形

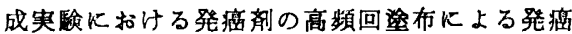
効果について，日口外誌 25：523 1979.

16）木村郁郎, 河西浩一，西崎主知，他：実驗的胹

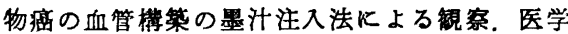
と生物学 77: 2171968.

17）田中敬一，永谷隆編：因説走查龟子䫓微鏡 一生物試料作製法一。第 1 版，朝倉畫店，東 京, 1980, 133頁.

18) Sekiba, K., Okuda, H., Fukui, H., et al.: A scanning electron microscope study of the fine angioarchitecture of the uterine cervix using a newly established cast formation technique. Obstet Gynecol Surv 34: 8231979.

19）岸好彰，高橋和人，㭬地千仍，他：口腔粘膜 に扣ける毛細管ループの立体的観察 1 舌。㐘 基礎誌 17: 1781975.

20) Bennett, H.S., Luft, J.H., Hampton, J.C.: Morphological classification of vertebrate blood capillaries. Am J Physiol 196: 3811959.

21）浜清：毛細血管の媺細構造. 血液と服管 3: 5611972 .

22）藤本 淳, 竹重順夫：血管内皮の棈造と機能. 細胞 4:2 1972.

23）藤田浄秀，賀来 亨，佐々木元䝨，他：舌㾔の 実豎的形成に関する研究第 2 編 舌癌形成過 程の組織学的研究. 口科誌 22: 64 1973.

24) Armstrong, P.B., Lackie, J.M.: Studies on intercellular invasion in vitro using rabbit peritoneal neutrophil granulocytes (PMNS) J. Role of contact inhibition of locomotion. J Cell Biol 65: 4391974.

25) Malech, H.L., Lentz, 'T.I..: Microfilament in epidermal cancer cells. J Cell Biol 60: 473 1974.

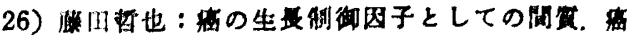
の臨床 18: 5961972.

27) Folkman, J., Cotran, R.: Relation of vascular proliferation to tumor growth. Int Rev Exp pathol 16: 2071976.

28) Philias, R.: Cytoplasmic polarization of periodontal ligament fibroblasts. J Periodont Res 14: 951979.

29) Wolf, J.E., Harrison, R.G.: Demonstration and characterization of an epidermal angiogenic factor. J Invest Dermatol 61: 1301973.

30) Folkman, J.: The vascularization of tumon. Sci Am 234: 581976.

31) Folkman, J.: Tumor angiogenesis factor. Cancer Res 34: 21091974.

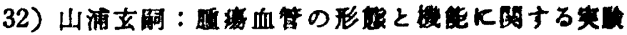
的研究。抗研誌 23: 1001971.

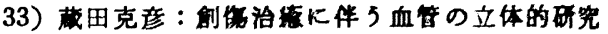
7.カイウサキの耳取作った切剑部の血管にっ いて。柴科医学 31：354 1968.

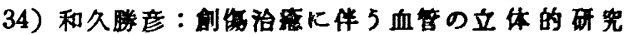

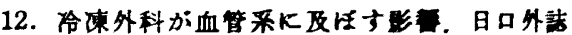
24: 1981978.

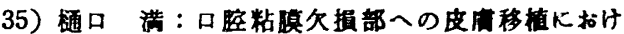

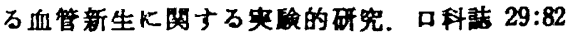
1980.

36) Converse, J.M., Smahel, J., Ballantyne, D.L., et al.: Inosculation of vessels of skin graft and host bed. A fortuitous encounter. $\mathrm{Br} J$ Plast Surg 28: 2741975.

37) Thomlinson, R.H., Gray, L.H.: The histlogical structur of some human lung cancer and the possible implication for radiotherapy. Br J Cancer 9: 5391955.

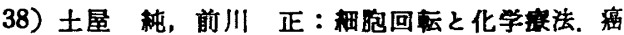
と化学法 5: 7171978.

39）杉村 隆，山村壦一闻：盘，岩波請座現代生物 科学 15 拳第 1 服，岩波書店，東京，1979， 248 頁.

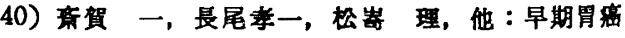

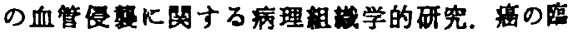
床 25: 10461979 .

41）山田英替：血管内皮の棈造と機能，血液と眽管 3: 5111972

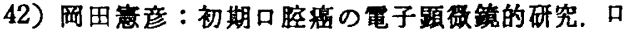
病誌 42: 1401975.

43）矢代昭夫：実跧的皮庙癌の電子影镜的研究. 昭医誌 34：601 1974. 


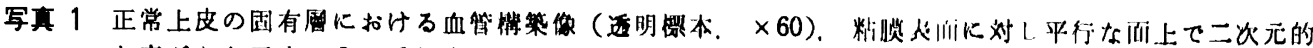
な広がりを示す。I：舌侧㦀肉

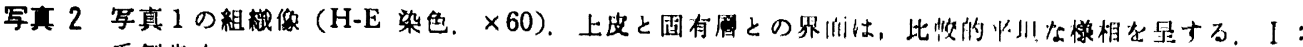
舌側菌肉

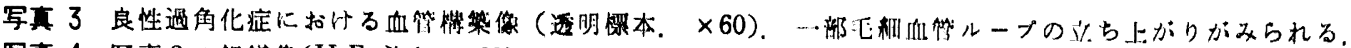

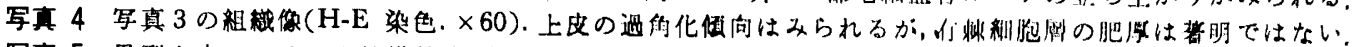

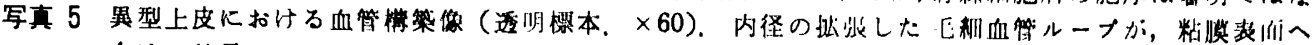
向けて伸長している。I：舌侧因肉

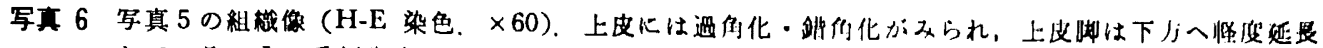
している，I：舌㑬懒肉

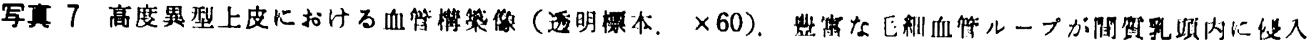
しており，血管密度は高くなっている。I：舌侧绦肉

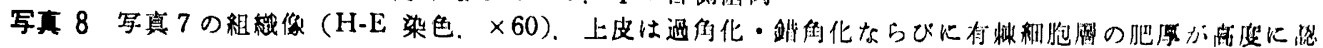

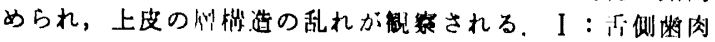

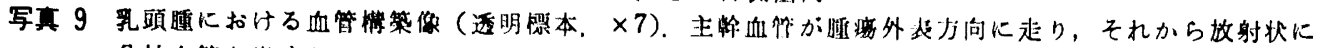

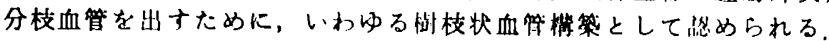

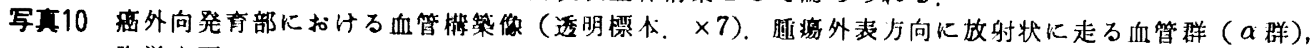

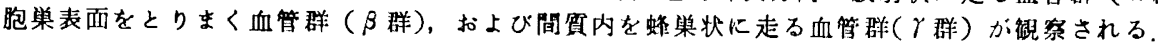

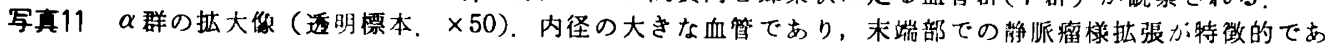
万.

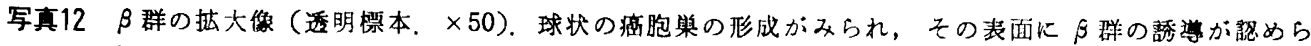
れる。

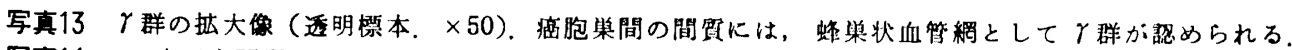

写真14-a 癌固有間資の豊富な腫掦(透明標本。 $\times 7$ ) $\alpha$ 群， $\beta$ 群および $\gamma$ 群すへての血管は良く発達してお $\eta$, hypervascularized tumor の钼を呈している。

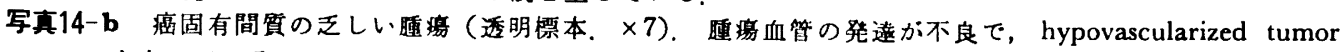
となっている。

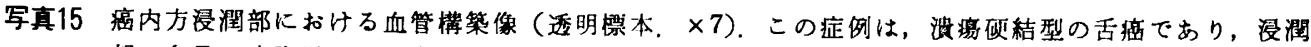

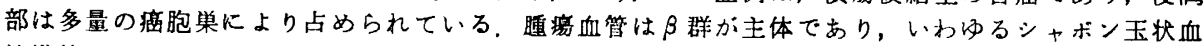
管構筑として認められる。

写真16 癌組織と正常組嬂との境界部（透明標本。×50)，筷出怡発育を示すところでは，正常組織より胞 单に向けて柵状の血管構築（矢印）を形成している。

写真17 畽場血管内皮稩胞 $(\times 16,000)$ 。指状あるいは波状形態をした luminal process (LP)が管腔へ突出し ている。

写真18 腫瘍血管内皮稩胞と pericyte $(\times 13,000)$. 左側の内皮細胞のよ5に，核のあるところでは特に管腔

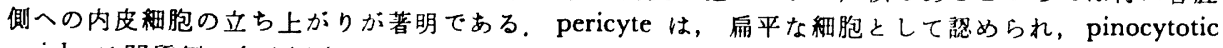
vesicle は間質側に多く覞察される。

写真19 腫瑒血管内皮細胞と pericyte $(\times 10,000)$ 。笛子密度がそれぞれ異なる種々の北態をなす内皮細胞 が, junctionを介して連続しているのが認められる。

写真20 腫瘍血管内皮細胞と pericyte $(\times 14,000)$. 内皮細胞の細胞質は明調を呈し, 多数の pinocytotic vesicle が散在している。内皮勫胞基底膜外側では，部分的に数風の pericyte による囲橈が観察さ れる.

写真21 fenestrated type の腫瘍血管 $(\times 6,000)$. 癌胞巣に近接する侧の内皮稩胞は，全体的に韭䔦であり

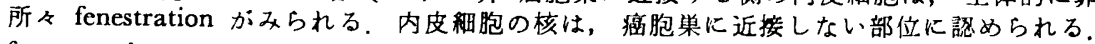

写真22 fenestrated type の腫瘍血管 $(\times 14,000)$. 瘦胞巣に近接するにしたがい, 内皮細胞は非常に扁平 化し部分的に fenestration が認められる. 插入写真: fenestration 部の扗大 $(\times 42,000)$.

写真23 continuous type の腫場血管 $(\times 10,000)$. 内皮細胞は高度に肥大し，管腔を狭窄してしま5はと である

写真24 continuous type の腫瘍血管 $(\times 24,000)$.この腫痒血管は, 電子密度がれそれ異なる内皮細胞 からなっている。

写真 25 continuous type の腫場血管 $(\times 13,000)$. 正常毛稩血管に比较的近似した構造をとっているが, 内皮細胞が所々こふ状に管腔側へ隆起しているのが特徵的である。

写直26 腫湟血管の立体的観察所見 $(\times 30)$. 盲管をなして尰瘍外表方向に走っているのが認められる

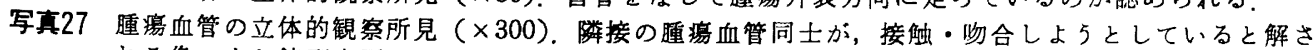

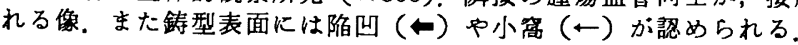

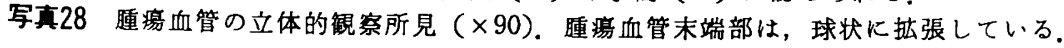



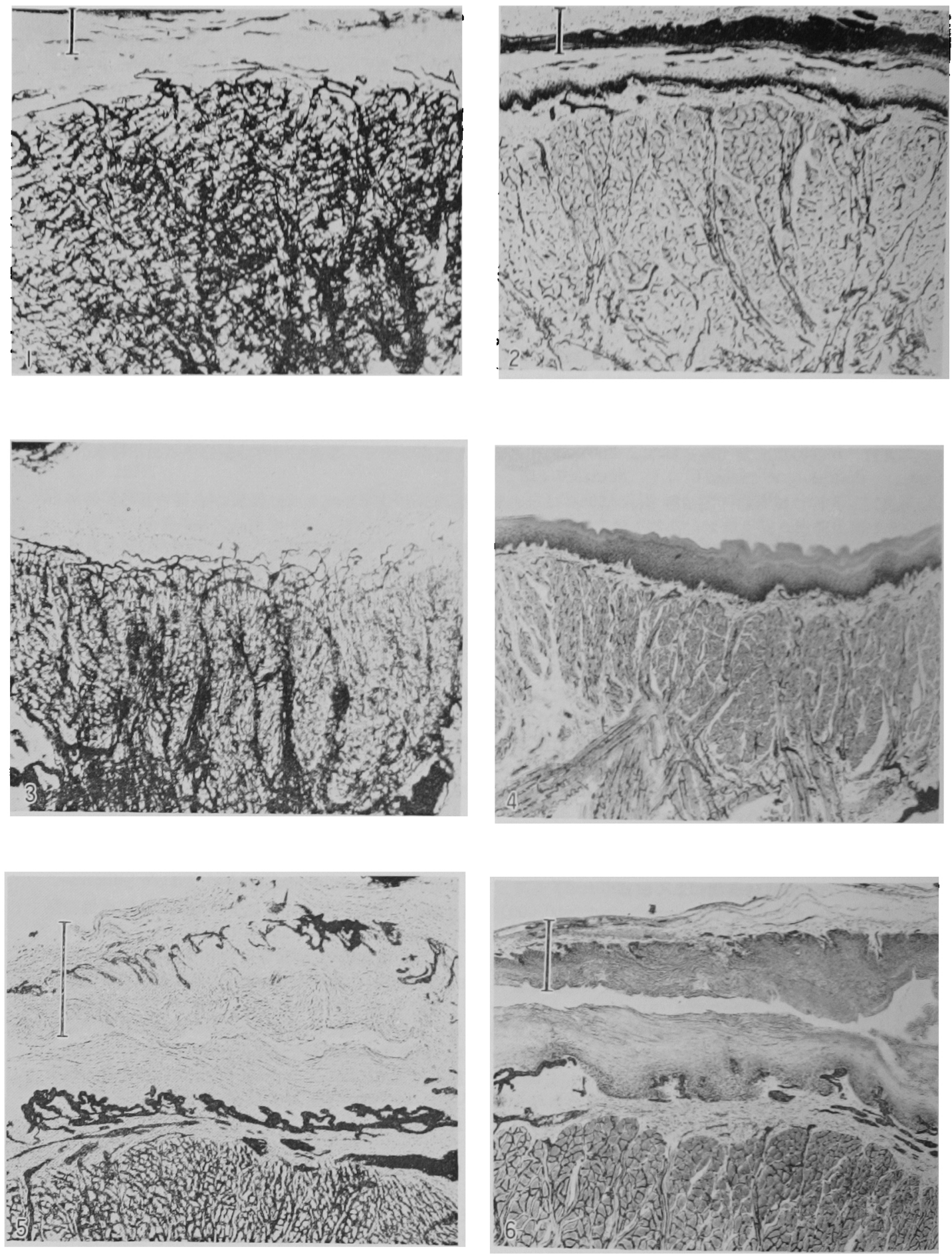

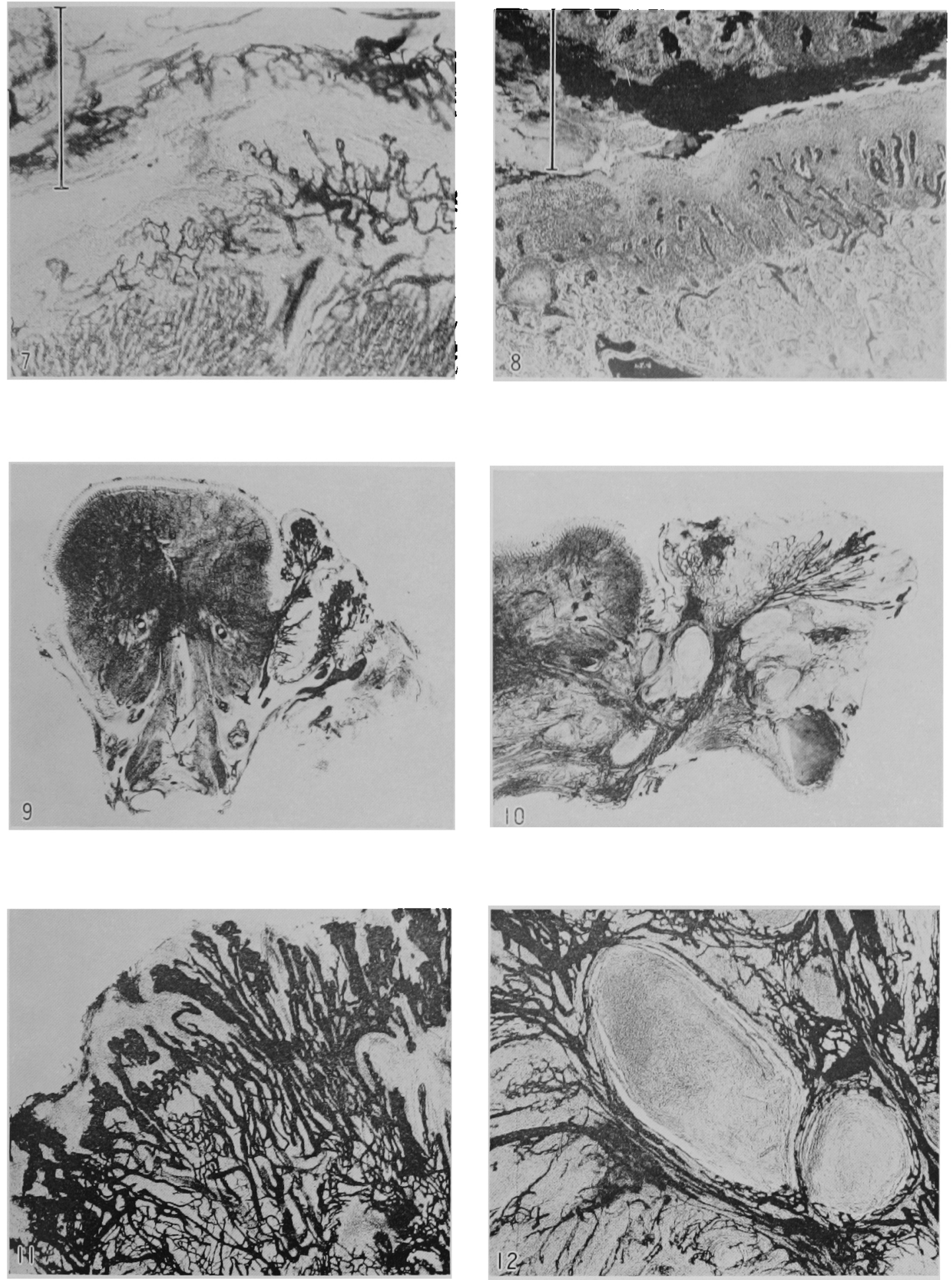

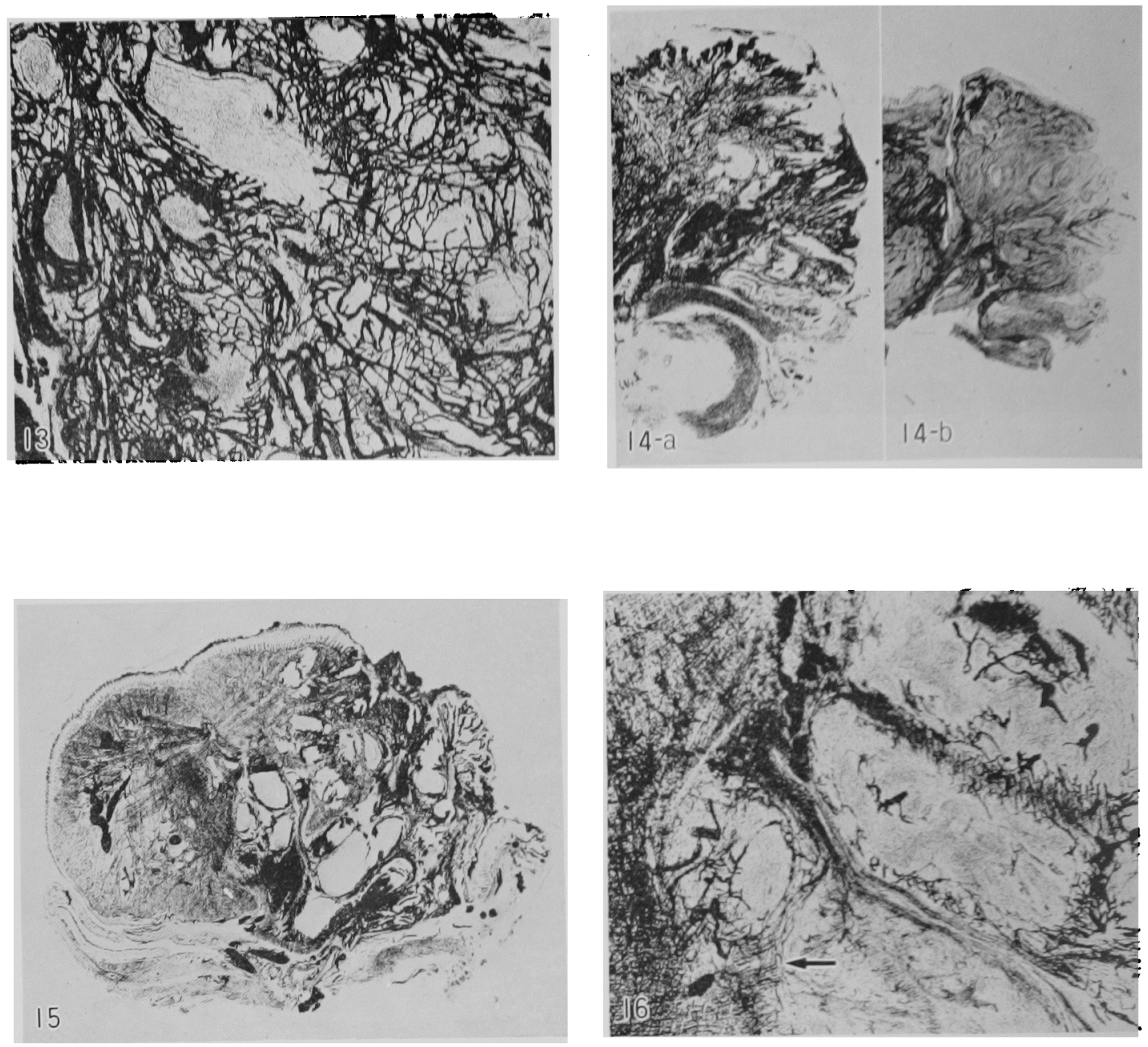

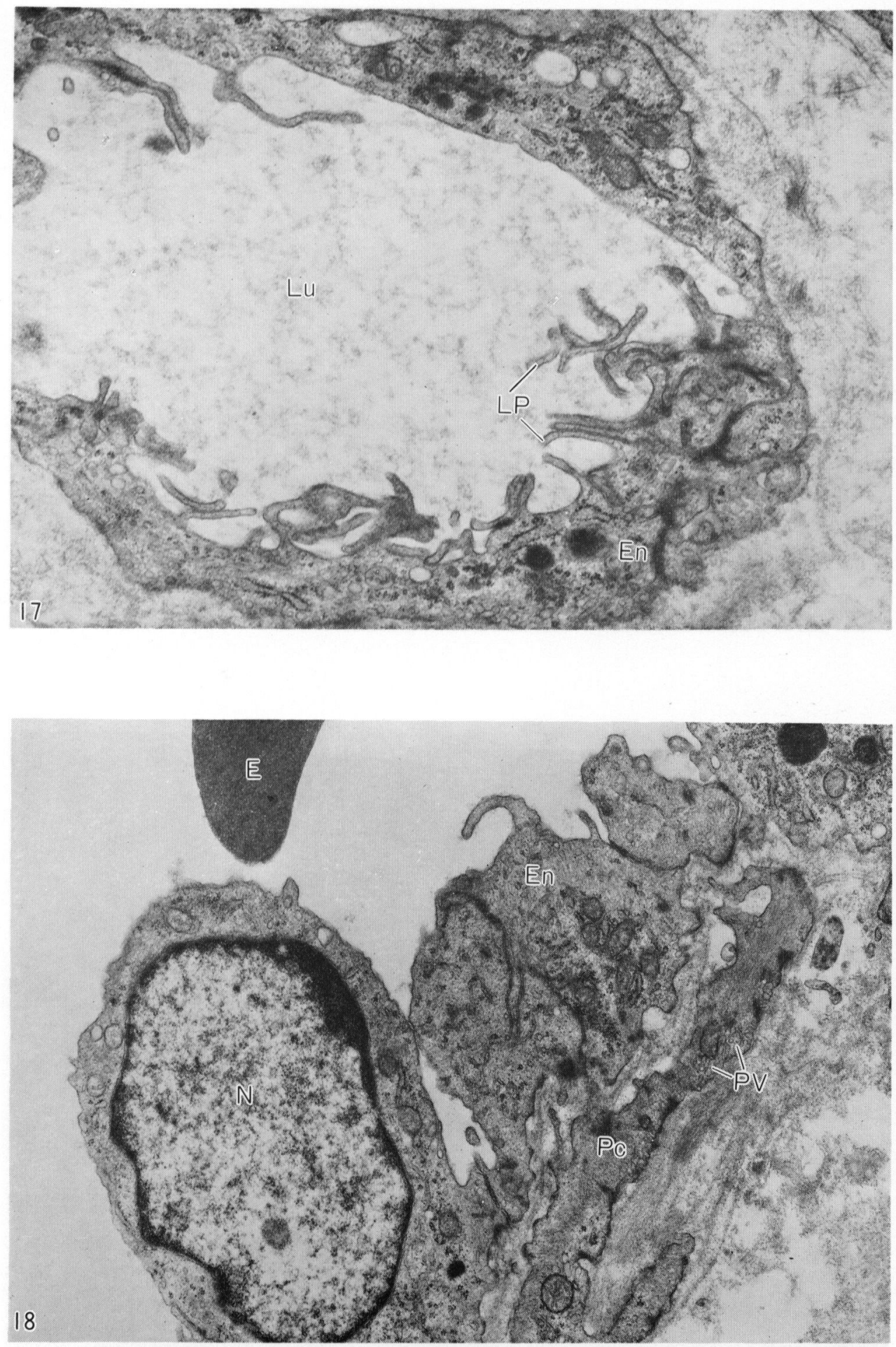

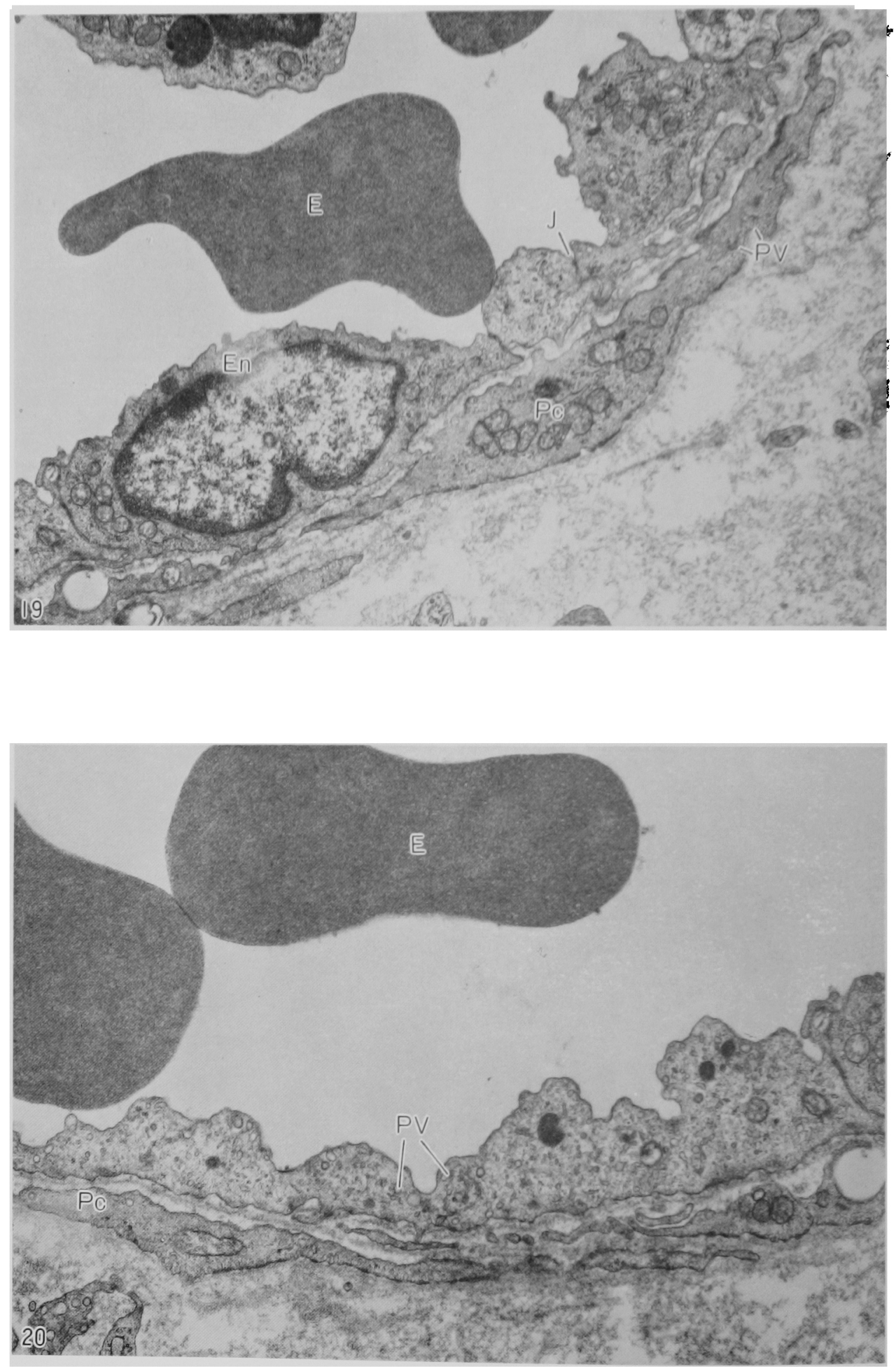

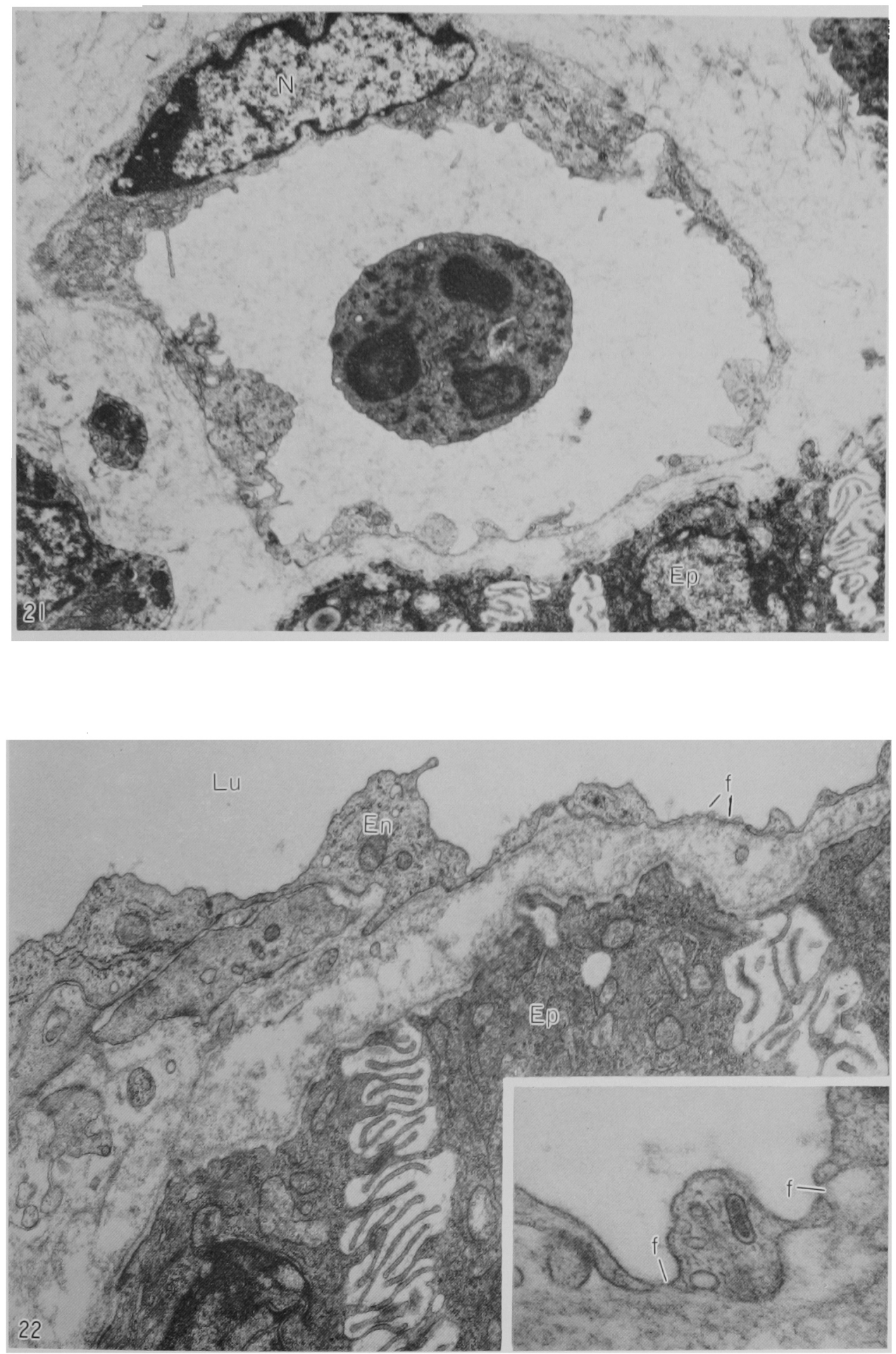

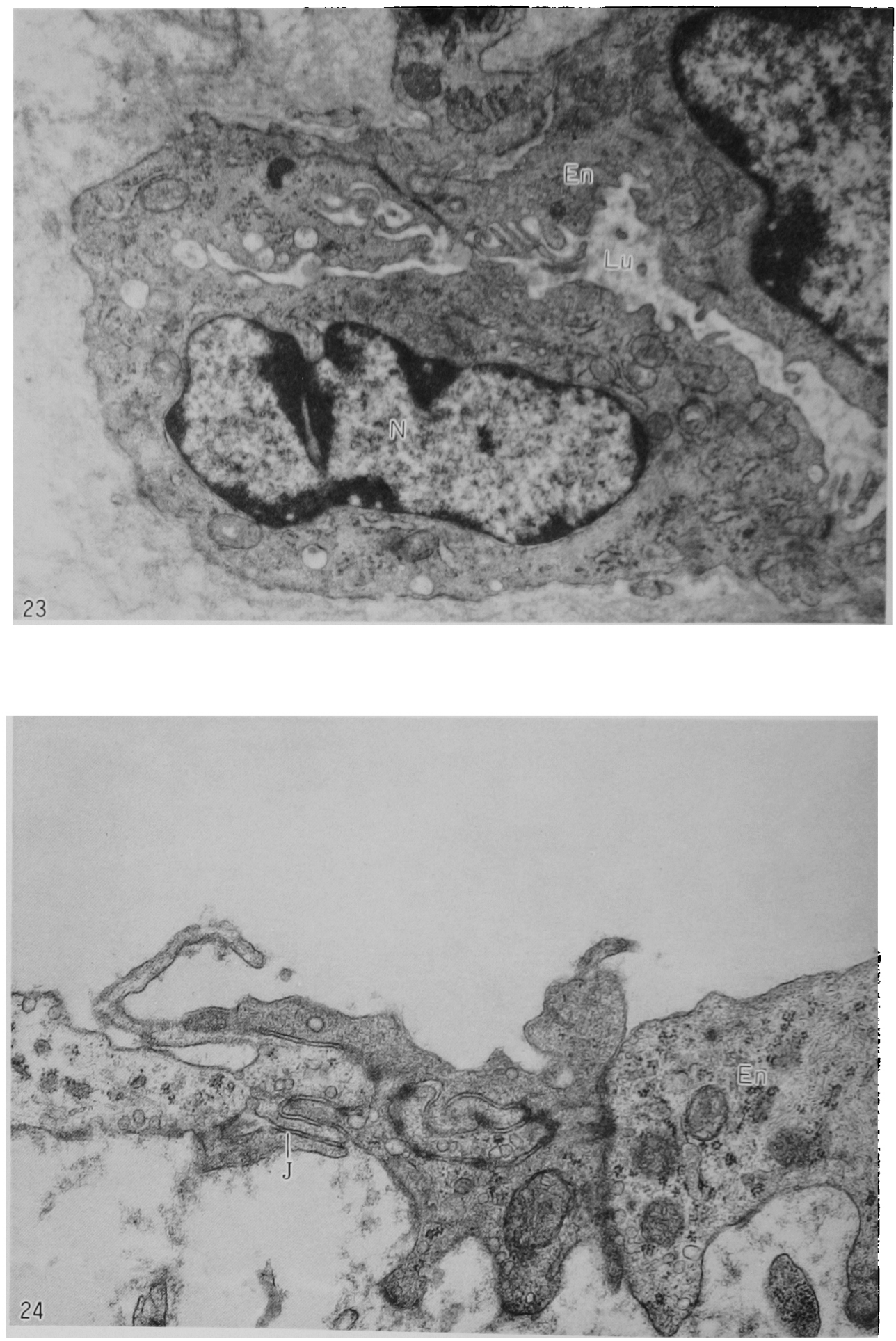

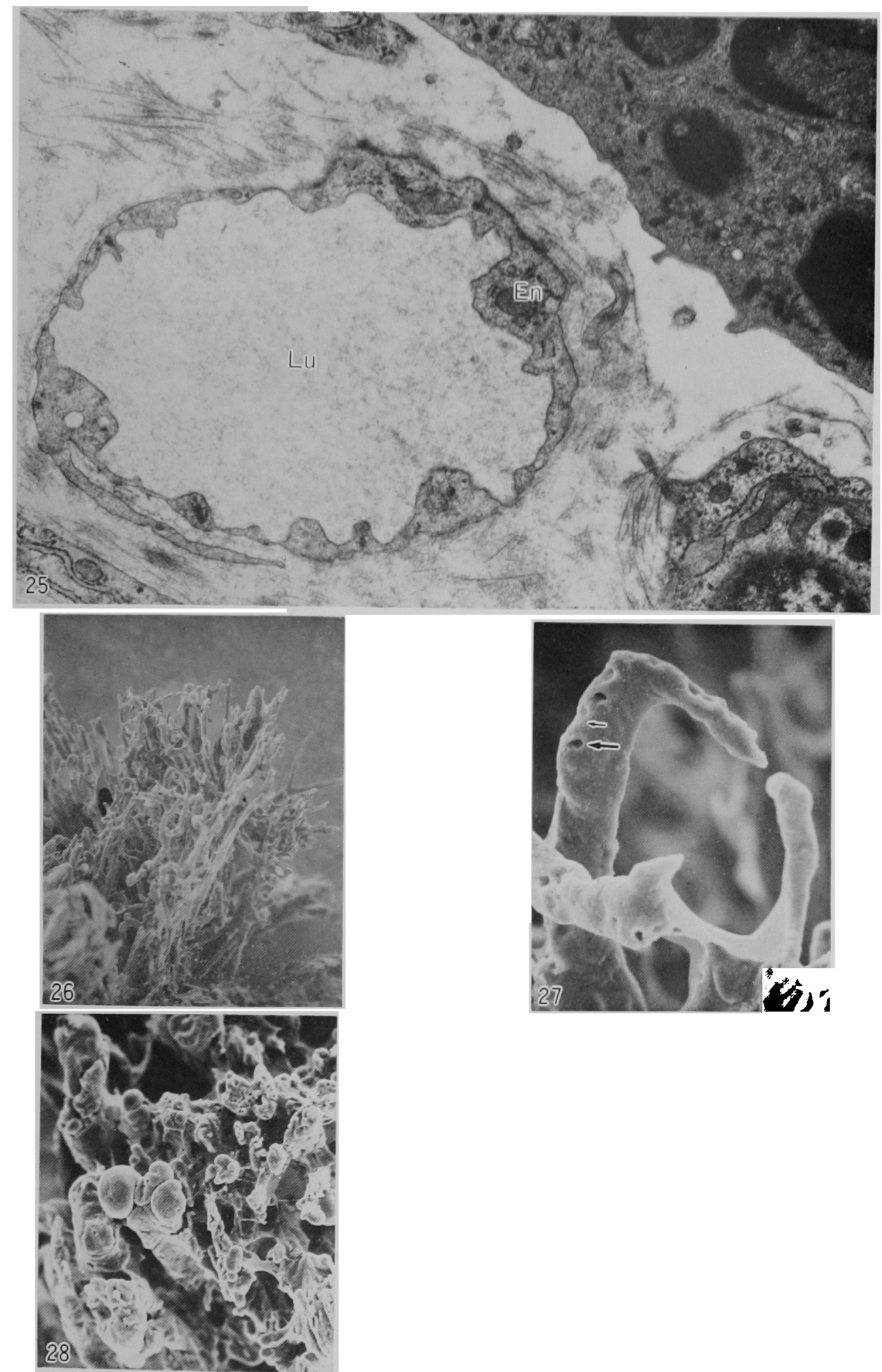